\title{
2章 NHKの中波ラジオ送信機
}

池上耕平 ${ }^{\dagger}$, 西森博行 ${ }^{\dagger}$,三須孝一 ${ }^{\dagger}$, 正会員天辰則博

キーワード : 中波, 送信機

\section{1. まえがき}

NHKでは, ラジオ第一 (R1) 放送, ラジオ第二 (R2) 放送 の二つのメディアで国内中波放送のサービスを行ってい る. R1はローカル放送を中心としたネットワークで構成, R2 は全国放送を基本とした広域ネットワークで構成し，日 本全国のあまねくサービスを実現している，一方，最近の 中波ラジオを取り巻く環境は, 2011年の放送と通信の融合 による電波法の改正では安全・信頼性の確保が定められ, また東日本大震災の発生を機に災害時の重要なメディアと して再認識されるなど, 高い信頼性が必要とされている. ここでは, 最新型の送信機を中心としてNHKの中波送信 機および送信設備について概要を紹介する.

\section{2. 中波送信機導入の歴史}

中波送信機は 1925 年の放送開始以来，真空管を使用して いたが, 1978年には電力増幅部に半導体 (MOS-FET), 変 調増幅部にPWM方式*1を用いた出力 $100 \mathrm{~W}$ の送信機を初 導入した. 図 1 にブロック図を示す. その後, 順次高出力 の送信機を開発し，1990年には出力 $100 \mathrm{~kW}$ の送信機を導 入した。そして更なる高効率化・高信頼化を目指して現在 の主流である「ディジタル処理型送信機」の開発に着手, 1994年に $10 \mathrm{~kW}$ 送信機を導入した. 1998年には国内最大出 力であるディジタル処理型 $500 \mathrm{~kW}$ 送信機を導入, 複数の 電力増幅器 (PA) を直列合成することで, 半導体でも大電 力送信機の導入が可能となった. 2011 年からは送信機の構 成を 2 台切替方式に統一したシステムの導入を進めている.

*1 PWM方式は変調信号を増幅する際, 変調信号に応じパルス幅を変化 させた PWM信号を生成し，増幅を行った後にLPFで音声を復元し， 高能率化を図る方式.

$\dagger$ NHK 技術局 送受信技術センター（放送網施設部)

"AM Transmitter of Japan Broadcasting Corporation" by Kouhei Ikegami, Hiroyuki Nishimori, Kouichi Misu and Norihiro Amatatsu (Transmission \& Reception Engineering Center, Engineering Administration Department, NHK, Tokyo)

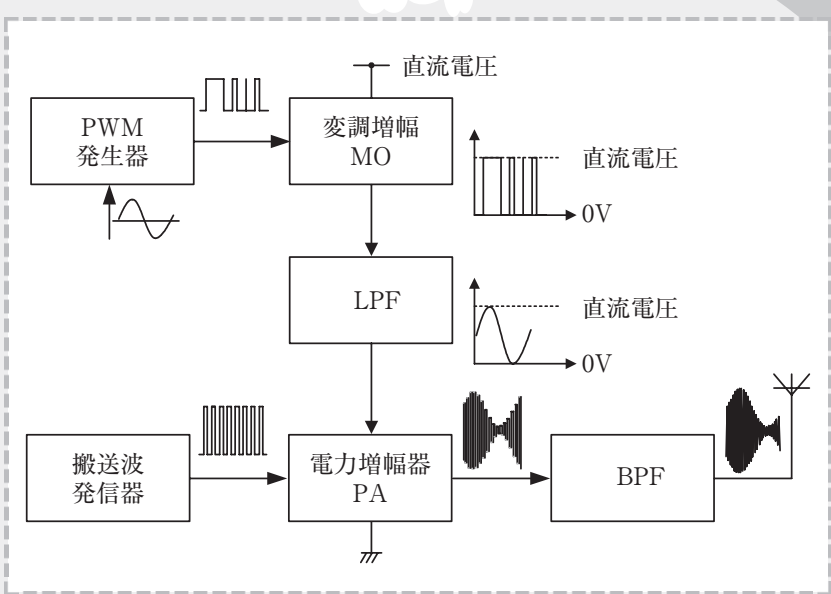

図 1 PWM方式中波送信機ブロック図

\section{3. 中波ラジオ送信機}

\section{1 動作原理とその構成}

ディジタル処理型送信機の動作原理を図2に示す。この 方式は音声信号をディジタル信号に変換し，そのビット信 号で ON/OFF 制御された複数のPA出力を合成し振幅変調 波を得る方式である.

送信機に入力されたアナログ音声信号は, DC成分を重畳 した後，A/D変換されディジタル信号に変換される．眓 2 の例では，12ビットのディジタル信号を用いて MSB (Most Significant Bit) 側 6 ビット, LSB (Least Significant Bit) 側 6 ビットに分けている. MSB側信号はエンコーダによって 10 進符号に変換され, その変換信号は 18 台の出力電力一定 (P0) の電力増幅器 (Bigstep PA) を ON/OFF 制御する. LSB 側信号は 2 進符号のまま, 信号の重み付けレベルに応 じて出力が $1 / 2 \mathrm{P} 0,1 / 4 \mathrm{P} 0,1 / 8 \mathrm{P} 0,1 / 16 \mathrm{P} 0,1 / 32 \mathrm{P} 0$, 1/64P0 と変化する binary PA 6 台を ON/OFF 制御する. $\mathrm{ON}$ 動作したPA出力を合成トランスで合成し, BPFを経由 することにより被変調波を得ている.

このようにディジタル処理型送信機は変調増幅部を持た ないため調整箇所が非常に少ない上に, 総合電力効率の大 幅改善も期待できる。

\section{2 中波送信機の区分について}

NHKが導入している中波送信機の出力は $50 \mathrm{~W} \sim 500 \mathrm{~kW}$ 


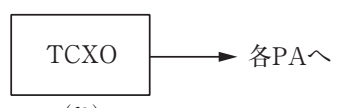

(f0)

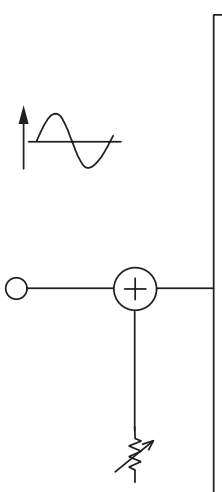

出力設定
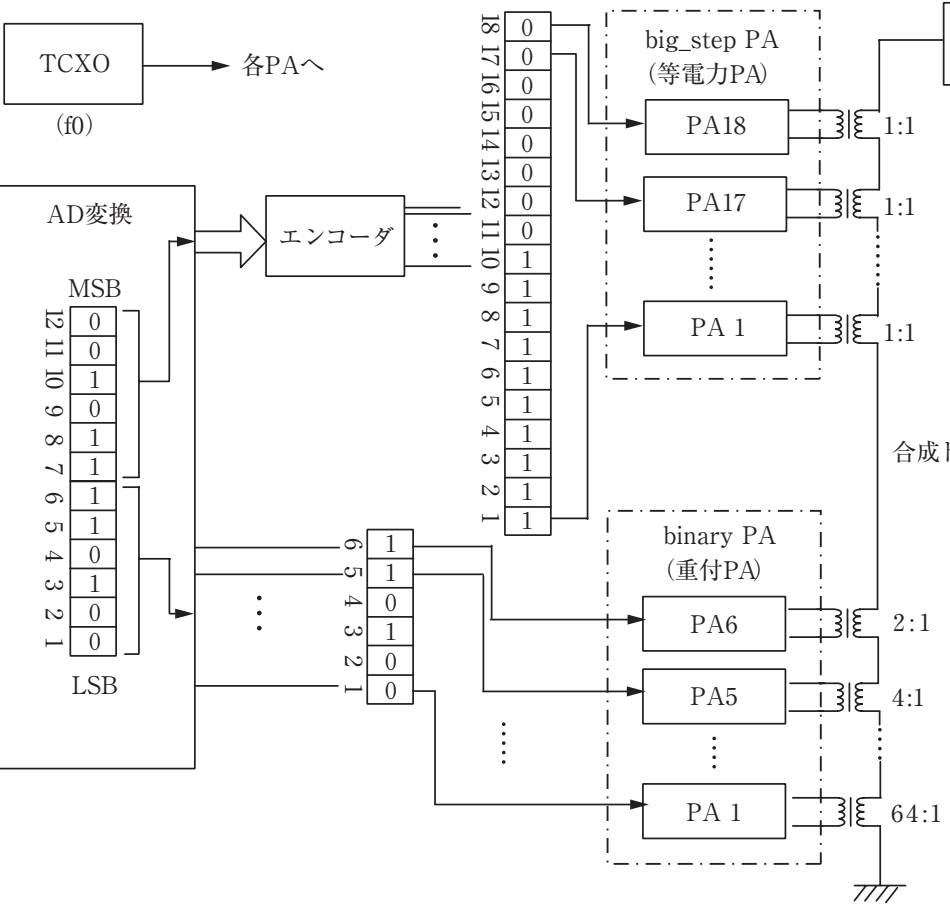

BPF

送信機出力

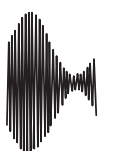

合成トランス

図2 ディジタル処理型送信機の動作原理

表 $1 \mathrm{NHK}$ 全国中波送信機数一覧

\begin{tabular}{|l|l|c|c|}
\hline \multirow{2}{*}{} & \multirow{2}{*}{ 出力/送信機数 } & $\mathrm{R} 1$ & $\mathrm{R} 2$ \\
\cline { 3 - 4 } & & 224 & 140 \\
\hline \hline 大電力 & $50 \mathrm{~kW} \sim 500 \mathrm{~kW}$ & 5 & 6 \\
\hline 中電力 & $300 \mathrm{~W} \sim 20 \mathrm{~kW}$ & 75 & 54 \\
\hline 小電力 & $50 \mathrm{~W}, \quad 100 \mathrm{~W}$ & 144 & 80 \\
\hline
\end{tabular}

*上記の他，離島を中心にFMによる送信機を14式導入している.

と非常に広範囲であるため, 送信機の種類も多岐にわたる. 表 1 にNHK 全国中波送信機数一覧を示す. $100 \mathrm{~W}$ 以下の送 信出力を小電力, $100 \mathrm{~W}$ を超え $20 \mathrm{~kW}$ までの送信出力を中 電力, $50 \mathrm{~kW}$ を超え $500 \mathrm{~kW}$ までの送信出力を大電力と 3 分 類し，それぞれのグループ内で共通仕様化を図り，送信機 を構成している。

\section{3 送信機のシステム構成}

送信機のシステム構成は真空管式送信機の時代から「3/2台 (切替) 方式」を採用し，各県の親局送信所に採用してきた. これは, 図3に示すように定格出力の $1 / 2$ 出力をもつ送信 部を 3 台設置し，このうち 2 台を合成して規定の送信出力 を得るものであり，ディジタル処理型送信機のシステムも これを踏襲してきた.

近年，放送のさらなる高信頼化を求めて検討を行った結 果，新たに 2 台切替方式を採用することとし，これまでの 仕様を変更して整備を進めている，放送電波の確保はもと より，製造コストや期間および各放送局での運用性を充分 に考虑して検討を進めシステム変更を実施した。開発にお いては，旧システムの仕様を積極的に活用し大幅な設計変

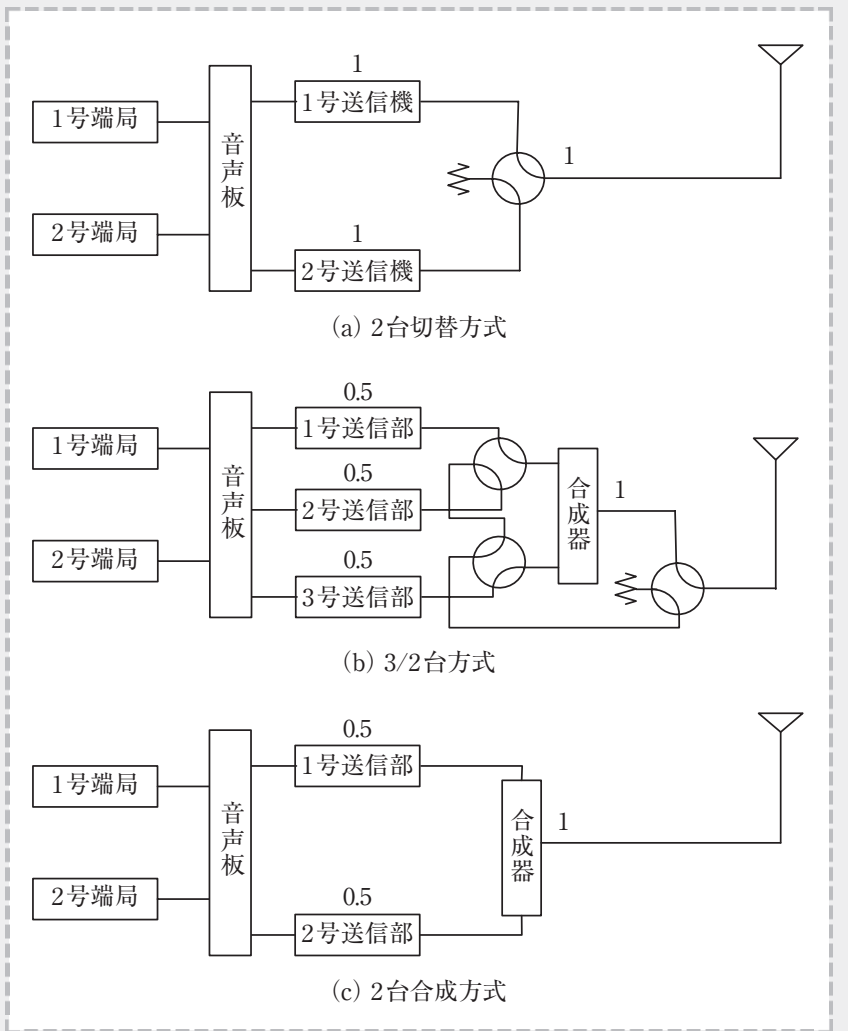

図3 中波送信機のシステム構成概要一覧

更を回避した．結果，効率的な設備整備を推進することが できている。

大電力送信機において，R1用送信機には 2000 年から先 行し 2 台切替方式を採用し，一部を除き R2 用送信機には 2 
台合成方式を採用している. それぞれが大電力送信所にお けるR1の 24 時間放送や送信出力規模に適応したシステム である。なお，2015年の大阪 R2 用 (羽曳野ラジオ送信所) 送信機更新をもって全ラジオ送信所の真空管式送信機の更 新を完了する予定である.

\section{4. 大電力用送信機}

大電力送信所は, 我が国最大の送信出力である $500 \mathrm{~kW}$ 送信所の 3 施設を含め全国で 10 施設あり, そのうち首都圈 ではおよそ2,000万世帯をカバーする重要な送信所の一つ である。それぞれの施設は図4 に示すように札幌から熊本 まで日本全国に設置されており，いずれも広域で放送サー ビスを行っている.

\section{1 大電力送信機構成}

表 2 に $300 \mathrm{~kW}$ むけ真空管式送信機とディジタル処理型送 信機の比較を示す。ディジタル処理型送信機は変調段を持

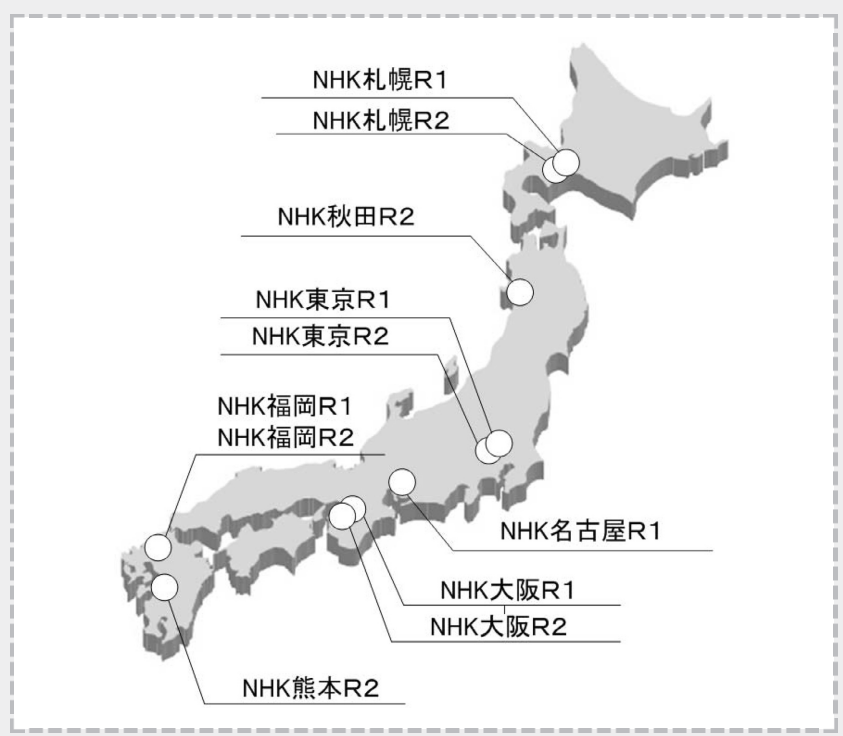

図4 全国の大電力送信所
たず，送信機の消費電力の大半が高効率 D 級増幅器 (PA) で消費されるため，真空管式送信機よりも2 割以上の省工 ネが可能である．図5に大電力送信機の例を示す。電源高 圧トランスや変調トランスは不要となり, 省スペース化に も大きく貢献している.

4.2 デュアルバンドシステムについて

図6にデュアルバンド送信機の系統図を示す，R2用送信 機にR1の送信機能を持たせ，R1の予備送信機として整備 している。この機能は東京 $\mathrm{R} 2$ 用送信機へ導入している. $\mathrm{R} 1$ 送信所での大規模補修など電波を停止して作業が必要な 場合，R2の休止時間帯にR1 用送信機に切替え 24 時間放送 を継続することが可能である。この機能を活用し，放送 サービスを継続しながら補修整備や点検等を実施する検討

\begin{tabular}{|c|c|c|}
\hline & 真空管式送信機 & デイジタル処理型送信機 \\
\hline $\begin{array}{l}\text { 方 式 } \\
\end{array}$ & \begin{tabular}{|l|} 
真空管式送信機 \\
変調：終段プレート変調 \\
デバイス：9F45R計6本
\end{tabular} & $\begin{array}{l}\text { 全固体化ディジタル処理型送信機 } \\
\text { 変調 : ディジタル処理型振幅変調 } \\
\text { デバイス：MOS FET } \\
\text { PA：約 } 300 \text { 台 (総数) }\end{array}$ \\
\hline $\begin{array}{l}\text { 構 成 } \\
\end{array}$ & \begin{tabular}{|l}
$150 \mathrm{~kW}$ 送信機 \\
2台並列合成方式
\end{tabular} & \begin{tabular}{|l}
$150 \mathrm{~kW}$ 送信機 \\
2 台並列合成方式
\end{tabular} \\
\hline 冷 却 & \begin{tabular}{|l|} 
蒸発冷却（水） \\
\end{tabular} & 強制空冷 \\
\hline 電源電圧 & DC12 kV & DC260 V程度 \\
\hline 総合効率 & 約 $60 \%$ & 約 $80 \%$ \\
\hline
\end{tabular}

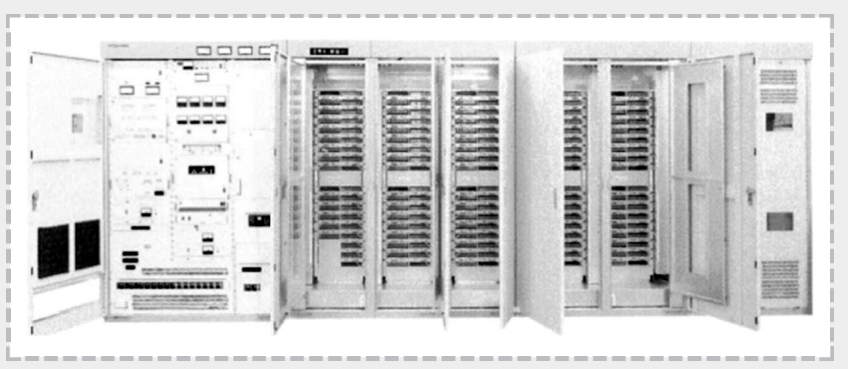

図5 大電力送信機 (150 kW送信部)の例

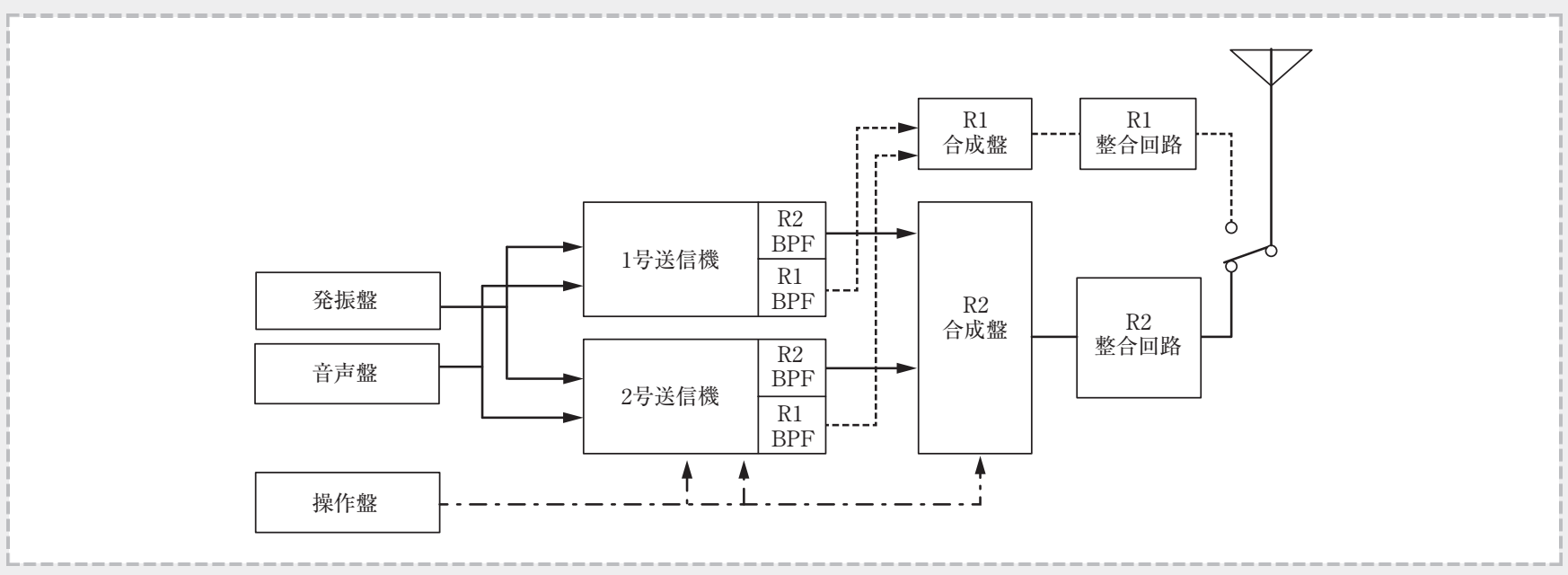


を進めている.

\section{5. 中電力用送信機}

NHK の中電力送信機は親局ならびに基幹放送用周波数利 用計画*2に記載された中継局が大部分を占めており, 各県 のローカル放送を支える重要な送信機として位置づけてい る.この中電力用送信機も大電力送信機と同様, 2011 年よ り送信機更新に合わせて 2 台切替方式を採用し, 整備して いる.

\section{1 中電力送信機構成}

中電力送信機は親局用として $1 \mathrm{~kW} ， 3 \mathrm{~kW} ， 5 \mathrm{~kW} ， 10 \mathrm{~kW}$, $20 \mathrm{~kW}$, 中継局用として $300 \mathrm{~W}, 500 \mathrm{~W}, 1 \mathrm{~kW}$ の出力で整 備している。図7に親局送信機の系統図, 図8に5kW 送信 機の構成例および外観を示す。送信機はオペレーションを 行う操作表示板や音声板などを収めている操作盤, 1 号送 信機, 2 号送信機, 切替盤およびダミー装置の 5 架で構成 し，3/2台方式送信機と同等の床面積で収まるよう省ス ペース化を図った。

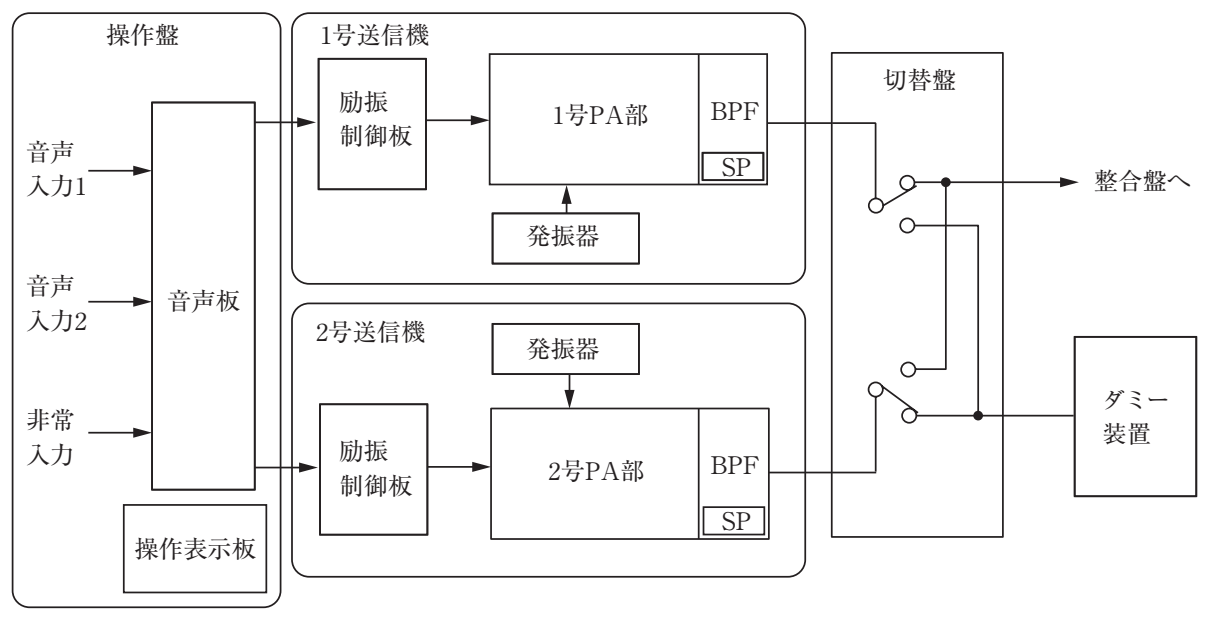

図7 親局送信機の系統図
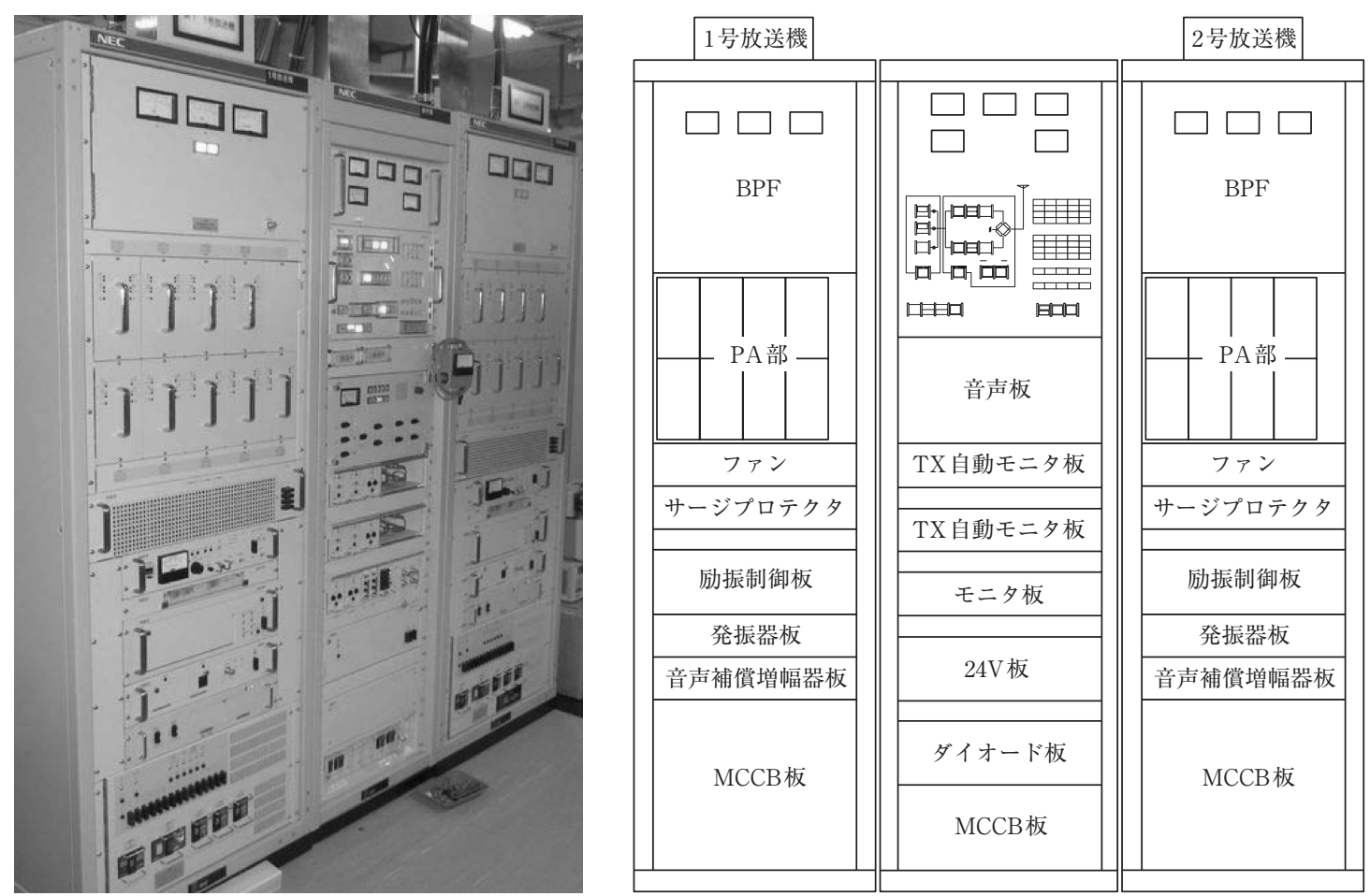

図8 $5 \mathrm{~kW}$ 送信機の構成例

* 2 1998/10/1 郵政省告示第六百六十一号の第7項. 
非常入力を含めた 3 系統の音声入力は音声板で切替えた あと， 1 号および 2 号へ分配する。音声板は能動素子を使 用しておらず，音声を補償増幅する機器は各送信部へ実装 している.

共通系設備は音声板の他，号機切替や監視制御を行う操 作表示板が該当するが, PA 部, 発振器, 励振制御部, 音 声補償増幅器などは完全 2 台化とし圥長系を持っており, 共通系の障害が発生した場合でも放送の継続が可能となっ ている.

中継局送信機は親局とユニットの共通化, 切替盤とダ ミー盤の1架構成，演奏所からの監視制御を行うリモコン 機能の簡略化などにより，省スペース化や低廉化を図った。 またR1およびR2の 2 メディアを運用している送信所では， 待機号機を含め送信機は 4 台となるが, 受電容量の増加を 避けるため，保守点検時には 4 台目の起動を制限する機能 を設けた。

\section{6. 小電力用送信機}

送信出力 50 〜 $100 \mathrm{~W}$ の小電力送信機は全国 144 局の送信 所で使用している.この小規模の送信所は送信機を収納す る局舎スペースが限られるため, 高信頼化と小型化が最優 先の課題であった。 2012 年から更新に合わせて整備を始め ている新送信機では，2台切替方式を選定し信頼性を向上 させるとともに大きく省スペース化した構成とした。

\section{1 小電力送信機構成}

図 9 に $100 \mathrm{~W}$ 送信機の全体構成を示す。音声入力を複数 系統化 (3入力) し，高信頼化を図っている. 図 10 に $100 \mathrm{~W}$ 送信機の外観例を示す. 最新型ではこれまで分割構造で あった送信部と電源部を一体構造とすることにより，省ス ペース化を図り，1メデイア当たり高さ $2,000 \mathrm{~mm}$ 標準ラッ ク 1.5 架程度のスペースで整備可能となった。

\section{7. 整合・二重給電子設備}

NHK ではR1 とR2の 2 メディアでサービスを行う送信所

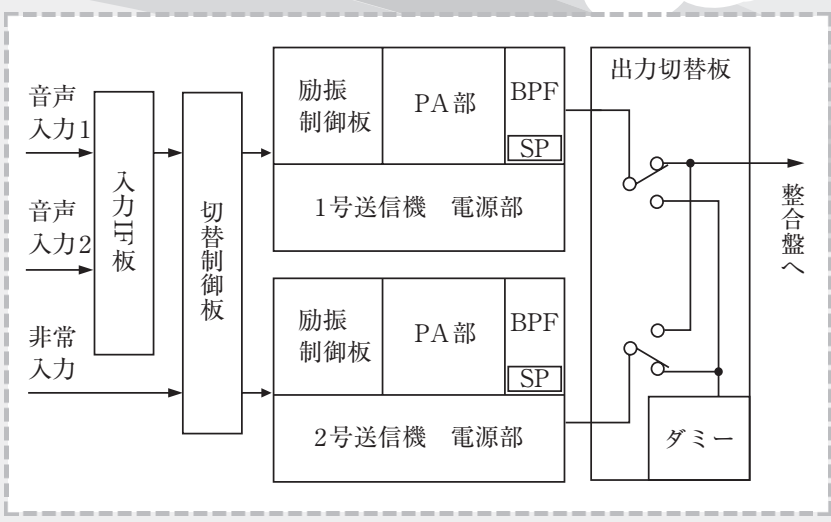

図9100 Wシステムおよび送信機構成図

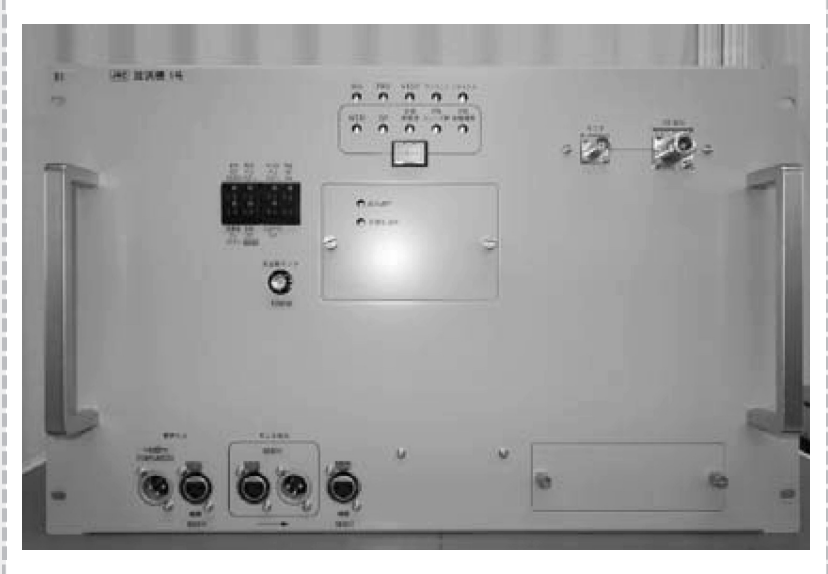

図 10100 W送信機

が半数以上を占めている. そのため, 空中線と送信機の マッチングを行う整合回路に加え，2メディア局には一つ の空中線で 2 メディアを共用する二重給電子も備えている. これら整合・二重給電子設備は $100 \mathrm{~W} \sim 100 \mathrm{~kW}$ までの出 力や周波数に応じて個別に設計している．また空中線から 誘導される落雷に対しては，空中線や二重給電設備でさま ざまな落雷対策を施し, 送信機への影響を低減化している. 図 11 に $100 \mathrm{~W}$ 小電力局に用いている整合回路および二重給

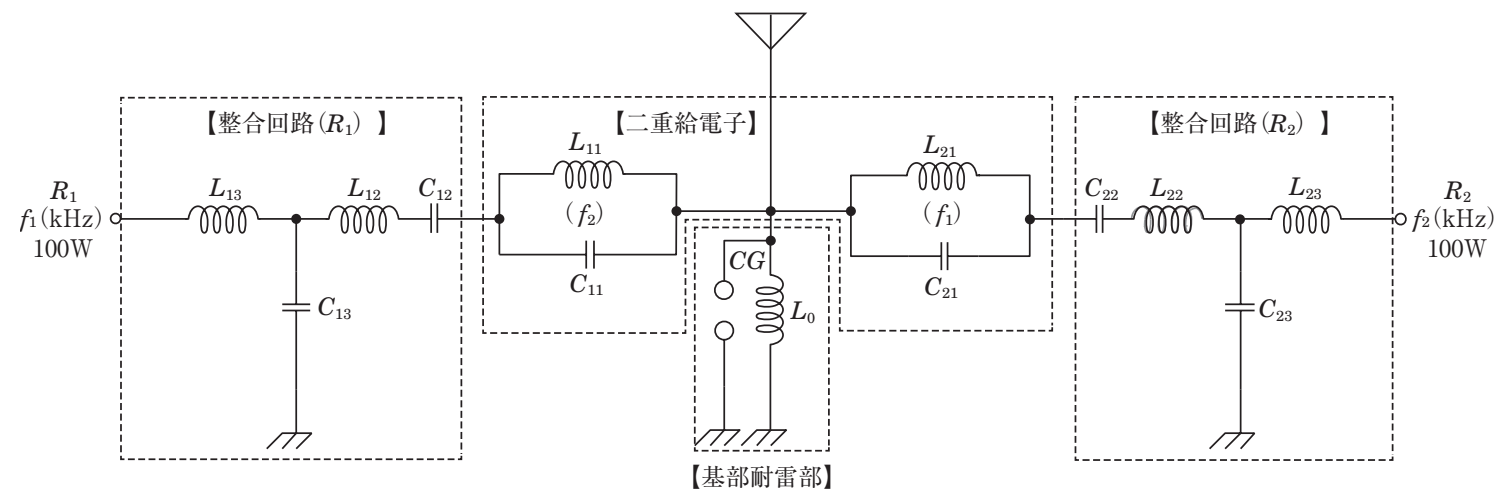

図 11 小電力局用整合·二重給電子構成例 


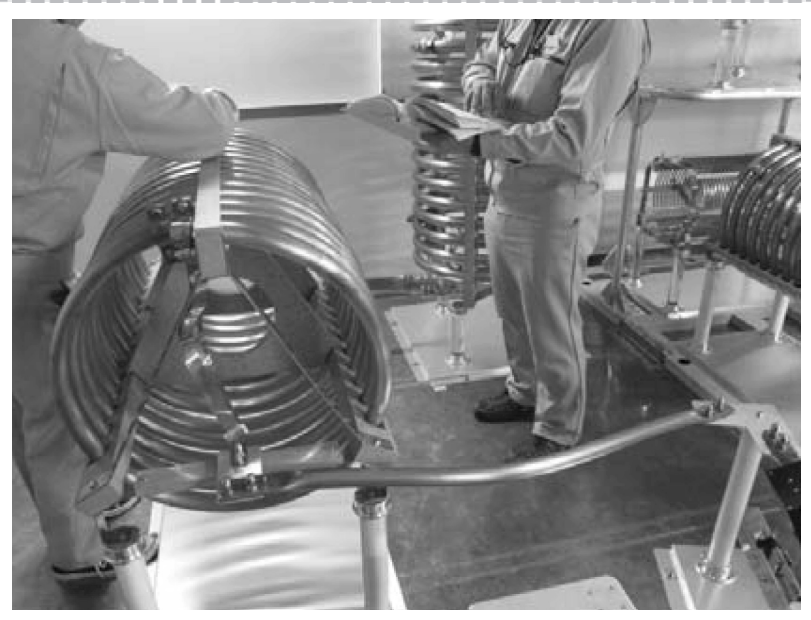

図 12 大電力送信所の整合回路外観

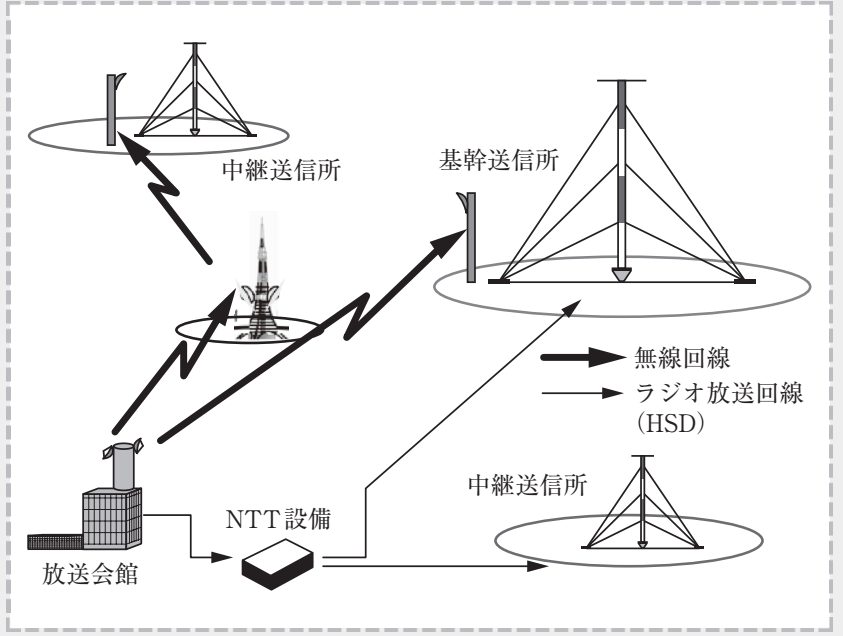

図 13 中波送信所のプログラム回線概要図

電子の構成例，図 12 に $500 \mathrm{~kW}$ 大電力送信所に用いている コイルの設置例を示す。

\section{8. 周辺設備の状況}

中波ラジオ送信機を構成する設備の中で, 特に近年の変 化が大きなものは，プログラム回線と送信アンテナである.

図13のように，中波送信所は親局および中継局ともに音 声プログラム回線が必要であり, 自営無線回線やNTT 専 用回線が用いられる. NTT 専用回線 (AM ラジオ放送線な ど）は従来のメタル回線から光回線に更新されており, 耐 雷性をはじめとしてその信頼性は大幅に向上した。一方， 自営無線回線の設備更新は周波数移行と連動しながら急 ピッチで全国整備を進めている.

基部絶縁式円管柱鉄塔を用いた送信アンテナは，定期的 に支線の更新を必要としている.NHKでは2011年から鉄 塔高が $100 \mathrm{~m}$ を超える大電力送信所の支線更新に着手し, これまで2局の更新を完了した(図14).

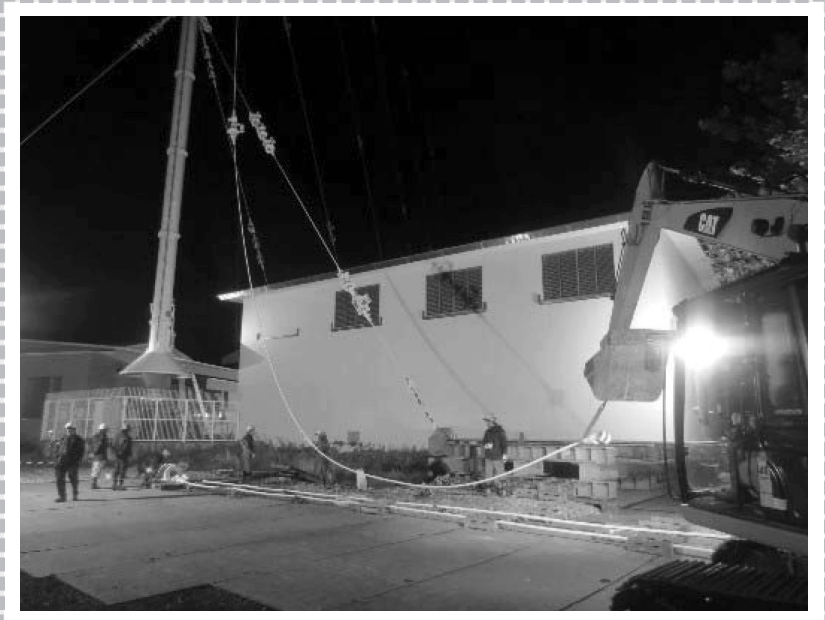

図 14 札幌R2の支線更新工事

\section{9. むすび}

放送開始から 90 年を迎えた現在，中波送信機や送信所を 構成する部品の確保が極めて困難な状況や，中波送信技術 力の継承など, 中波を取り巻く環境は年々厳しさを増して いる，そのような環境下であるが，中波ラジオ放送は，非 常災害時にはライフラインを確保する情報を届ける重要な メディアでもあるとともに, 普段の生活に密着したメディ アであり，多くの方々に親しまれ続けている．今後も放送 の安定確保と品質の向上に向けて取組んでいく.

（2014年11月 27 日受付）

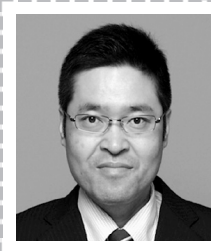

池上竦耕平 1988 年, NHKに入局。带広放送局, 菖蒲久喜ラジオ放送所，テレビ中央送信室，福岡放送 局を経て，2011年より，技術局送受信技術センター にて，中波送信機の設備整備に従事.

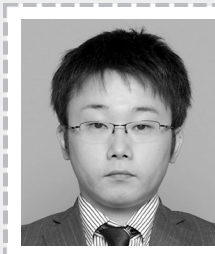

西菻博行 2001年, NHKに入局。宮崎放送局, 菖蒲久喜ラジオ放送所を経て，2007年より，技術局 送受信技術センターにて, 中波送信機の設備整備に従 事.

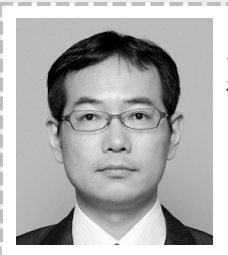

三須孝一 1997年，NHKに入局．青森放送局， 技術局送信技術センター, 菖蒲久喜ラジオ放送所を経 て，2013年より，技術局送受信技術センターにて， 中波送信機の設備整備に従事.

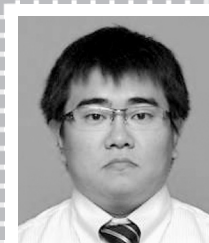

展則博 2003 年, NHKに入局. 宮崎放送局 を経て，2012年より，技術局送受信技術センターに て, 中波送信機の設備整備に従事. 正会員. 